\title{
Raising Awareness of Researchers-in-the-Making Toward Responsible Research and Innovation
}

\author{
Miklós Lukovics ${ }^{1}$ • Beáta Udvari ${ }^{1} \cdot$ Nikoletta Nádas $^{2} \cdot$ Erik Fisher $^{3}$
}

Received: 3 July 2017 / Accepted: 17 November 2019 /Published online: 2 December 2019

(C) The Author(s) 2019

\begin{abstract}
Across the globe, research, development, and innovation (RDI) processes are operating at increasingly accelerated paces, promising rapid development and higher standards of living, but also increasing the likelihood of unintended, socially undesirable effects that inevitably attend progress. The notion of responsible research and innovation (RRI) has emerged in response to this dilemma, and the integration of RRI into daily RDI practices itself represents a considerable challenge. Integrating RRI concepts and practices at an early or even pre-career stage, before researchers fully develop their daily routines, could strengthen the assimilation of RRI into RDI more generally. Thus, in line with the emphasis of RRI on science education, how to integrate RRI aspects in the thinking of researchers-in-the-making before they start their active research carrier is an important but under-investigated question. In addition, the special features of Generation $\mathrm{Z}$ currently being in higher education suggest the use nontraditional tools in science education.

Accordingly, this exploratory study asks how the RRI-awareness of researchersin-the-making can be raised. We adapt the Socio-Technical Integration Research (STIR) method, which facilitates reflection on societal aspects during scientific research practices and decisions, to the context of science education. We test the introduction of STIR among researchers-in-the-making studying natural sciences at the University of Szeged (Hungary). Our findings suggest potential steps for science education on RRI with attention to the special needs Generation $\mathrm{Z}$ and facilitating their RRI awareness for their active researcher career.
\end{abstract}

Keywords Responsible research and innovation - Socio-Technical Integration Research • Generation Z · Science education

Beáta Udvari

udvari.beata@eco.u-szeged.hu

Extended author information available on the last page of the article 


\section{Introduction}

Nowadays, the need for research, development, and innovation is unquestionable: knowledge, technological change and innovation are necessary factors of economic growth (Dosi, Grazzi, \& Moschella, 2015; Edquist, 2005; Khorseed, 2017), on the one hand, and they are causing large-scale changes and affect almost all aspects of life (Beck, 1992; Swierstra, 2013). Thus, alongside their positive effects, innovations may have - often indirect - drawbacks for which it takes years to occur. Formal governance and regulation are not enough to mitigate these undesirable consequences: researchers and innovators also have a role to play in reflecting on and anticipating the future effects of their research and development - both positive and negative social, ethical, and environmental - during their routine decision making practices (Owen et al., 2013). This logic draws the attention to what has recently been denoted responsible research and innovation (RRI), since it tries to reveal how researchers could make more conscious decisions.

The implementation of theoretical results of RRI into practice, however, raises several scientific and practical questions. Several recent studies have suggested tools and methods for engaging active researchers in this respect (e.g., Hin et al., 2015; Pavie \& Egal, 2014), although they are still under testing. Alongside these efforts, it is important to consider whether and if so how RRI aspects can be incorporated in the thinking of researchers at an early stage, before they undergo formative work experiences. Accordingly, we argue that science education as one of the six "RRI keys" (EC, 2014) can play an important role not only in engaging publics but also in preparing experts for more robust relations between science and society. There are some attempts to integrate RRI concepts into (university) formal, classroom education in terms of science education (Okada, 2016), into ethics education (Spruit, 2014), or into educational policies in the USA (Richter, Hale, \& Archambault, 2019). Nevertheless, can formal, classroom educational programs be supplemented by methods that have been shown to be effective among active researchers? This question takes on particular importance when we recognize that the current generation of the researchers-in-themaking (Generation $\mathrm{Z}$ ) is the first one who socialized in a digital world, which potentially poses new challenges to the education system. All these raise the question how the RRI awareness of researchers-in-the-making can be raised.

Based on the special characteristics of the Generation $\mathrm{Z}$ (e.g., nonlinear learning, need for active participation, multitasking) (Geck, 2007; Oblinger \& Oblinger, 2005; McCrindle \& Wolfinger, 2009), we investigate the value of applying a method other than one adapted to the traditional classroom setting. As a first step, we turned to the RRI tools ${ }^{1}$ implemented so far.

Among these methods, the Socio-Technical Integration Research (STIR) has a demonstrable record of achievement: since 2006, STIR has been applied effectively among active researchers in more than 50 laboratories and other organizations in both developed and developing countries (e.g., Fisher, 2010; Flipse \& van de Loo, 2018; Flipse \& Osseweijer, 2013; Lukovics, Fisher, \& Udvari, 2016; Lukovics, Flipse, Udvari, \& Fisher, 2017; Richter, Tidwell, Fisher, \& Miller, 2017; Schuurbiers \& Fisher, 2009). Although STIR has a relatively long history, it has not been employed as a tool

\footnotetext{
${ }^{1}$ For example, living labs, RI standards, design thinking, etc.
} 
in science education yet, but because of its long track-record and significant results, we test it in a specific RRI level.

Thus, the aim of the present exploratory study is to test how the RRI awareness of researchers-in-the-making can be raised. Since traditional educational methods (e.g., front-teaching) are relatively unsuccessful among the Generation $\mathrm{Z}$ students (at least in secondary school - see, e.g., Barnes and Noble College, 2017), the present research goes beyond how to incorporate RRI in course descriptions and focuses on the application possibilities of a nontraditional tool in science education. Thus, we test an adaptation of the STIR method as a modern tool in science education using qualitative research with Hungarian university students from Generation Z (born after 1995). All students study natural sciences at the University of Szeged (Hungary) and are determined to pursue a research career in a research institution (either in the academia or in the private sector). This paper contributes to the current literature with analyzing a Central-European country in terms of adapting responsible innovation, on the one hand, and with investigating how effective the STIR method can be among the university students from Generation $\mathrm{Z}$ (as potential researchers). This research is the first attempt to respond to these issues.

In the first part of the current paper, we review the theoretical background of RRI and science education; then we describe the STIR method as an approach for implementing RRI in practice. Subsequently, we present the main properties of the Generation Z. In the second half of this paper, we present the background and the results of STIR research on the involved natural science students. Finally, we suggest how to further adapt STIR - as a new tool in science education - on young, not yet practicing researchers.

\section{Responsible Research and Innovation}

Investments in research and innovation are meant to seek solutions to pressing economic, environmental, and social global problems, by which opportunities and living conditions of both the present and future generations could be improved. Rapid technological development, however, can lead to undesirable consequences that possibly influence human life for a long time. Learning from the past (Adam \& Groves, 2011), the strengthening role of public opinion (Sutcliffe, 2013), declining trust in expert institutions (Sutcliffe, 2013; Wynne, 2006), the emergence and acceptance of progressive concepts such as mode 2 science (Gibbons et al., 1994), and sustainable development (Buzás \& Lukovics, 2015) have contributed to the push for more socially responsible RDI practices, thus the articulation of RRI.

\section{The Concept of Responsible Research and Innovation}

RRI has become an important concept throughout the industrialized world. The concept itself emerged in the USA at the Millennium together with the concepts of responsible innovation, responsible research, and responsible development (Owen, Macnaghten, \& Stilgoe, 2012). In the European Union, this approach appeared a decade later, even though the EU finds environment protection and the reaction on social needs important (EC, 2013). In the EU, the need to consider social and ethical issues during RDI 
processes appeared in the Lund Declaration published in 2009 and in the Social Dimension of the European Research Area issued by the Council of the European Union in 2010 (EC, 2013). Meanwhile, RRI has become a significant element of the EU's Horizon 2020 research program. RRI is a key action of the "Science with and for Society" program of Horizon 2020, and it is considered as an effective instrument to enrich cooperation between science and society (Owen et al., 2013).

The roots of the RRI can be found in management and other scientific research (Inzelt \& Csonka, 2014; Owen et al., 2012), so there are several definitions available referring to its inter- and multidisciplinary manner (Buzás \& Lukovics, 2015; Chorus, van Wee, \& Zwart, 2012; Owen et al., 2012; Sutcliffe, 2013; Tihon \& Ingham, 2011). These explanations commonly emphasize social responsibility but consider environmental and ethical responsibility differently, and only some highlight the importance of open innovation and transparency (Buzás \& Lukovics, 2015). Although the RRI definitions vary researchers by researchers, we find that the definition most accepted by the scientific community is created by von Schomberg (2013: 63): "RRI is a transparent, interactive process by which societal actors and innovators become mutually responsive to each other with a view to the (ethical) acceptability, sustainability and societal desirability of the innovation process and its marketable products (in order to allow a proper embedding of scientific and technological advances in our society)." Consequently, RRI highlights collaboration among the actors of innovation. We also rely on this definition during our research work.

Attempts to guide the implementation of RRI in practice vary. Scholarly frameworks emphasize process principles such as anticipation, inclusion, reflexivity, and responsiveness (Stilgoe, Owen, \& Macnaghten, 2013). Research policy organizations sometimes reinforce these ideas, often while pursuing specific programs (Owen, 2014).

Although RRI scholars and research policy organizations alike emphasize the need to integrate RRI into the daily operations of research institutions and researches (Arnaldi et al., 2015; Forsberg et al., 2015; Shelley-Egan, Hanssen, Landeweerd, \& Hofman, 2018), it is not always clear how to do this. There are some results suggesting that involving civil society organizations into RI project would have positive impact on diffusing the RRI concept (Ahrwiler, Gilbert, Schrempf, Grimpe, \& Jirotka, 2019). And while the nature of the relationship between scholarly and bureaucratic frameworks is disputed (Rip, 2016), we focus next on the European Commission's notion of science education as an opportunity to implement other aspects of RRI by promoting greater societal awareness among scientific researchers. This question is extremely important when one considers the limits of responsible research and innovation and which address the questions (Hoop, Pols, \& Romijn, 2016): innovate responsibly or not innovate at all? With the education of the researchers-in-the making, this question remains at stake.

\section{The Importance of Science Education in RRI}

Science education and science literacy have become prominent components of RRI in encouraging its notion of responsible citizenship (EC, 2015). The main objective of science education in the RRI policy is "to build effective cooperation between science and society, to attract youth toward scientific studies and careers, to pair the interest of youth in science with social awareness and responsibility, and to help them to become 
more active citizens in the field of science" (EC, 2017, p. 41). Science education was originally integrated into the school curriculum in order to provide a background for those seeking to continue their studies in the field of science at the university (Fensham, 2008), but its role seems to have changed (Holbrook, 2010). This is because of an increased awareness of the influence that science can have in all fields of social life (Fourez, 1997; Gurría, 2011; Holbrook, 2010), fueling interest in linking science subjects with all other subjects in education (EC, 2015; NASEM, 2018).

Based upon this observation, in combination with a holistic consideration of the other European keys that emphasize ethics, governance, gender equality, and engagement of all relevant societal actors in the innovation process, it is clear that from an RRI perspective, science education cannot be limited to attracting new talent into the science and engineering pipeline. In addition to this goal, science education is also a way to expand the knowledge of future generation scientists to attend to innovation processes in more socially robust and responsible ways. In other words, science education should help young people to realize how they can contribute to shaping the world as responsible citizens (Jenkins, 1999) and how they can contribute to the management of risk and uncertainty through the guidance of technological development and innovation in the present (EC, 2015; Owen et al., 2013). On this understanding, science education should not only contribute to personal well-being but also support participation in the innovation endeavors that are deemed essential for understanding and shaping the world (EC, 2015).

Although science policy organizations such as the European Commission emphasize the importance of science, science education faces challenges all over Europe. Science literacy is varied across Europe (Sinatra, Kienhues, \& Hofer, 2014), not to mention the gender, cultural, and regional disparities concerning the participation in science education (Ballas et al., 2012). Moreover, the interest in scientific studies and careers has declined in the previous years (Olsen \& Lie, 2011). Additionally, there are ongoing debates about the need for new methods and content in the educational system to make science careers attractive to the current generation of young persons (Inzelt \& Csonka, 2014).

Ideally, approaches to science education will combine activities that synergistically enhance scientific creativity and societal responsibility. In meeting both of these objectives, it is crucial to enhance the curiosity of students. For this purpose, emphasizing creativity and innovative, useful, and engaging experimentations with knowledge instead of simply focusing on students' ability to memorize facts (Hayden, Ouyang, Scinski, Olszewski, \& Bielefeldt, 2011) may be a promising way to proceed. Before we describe our approach to science education in an RRI context, in the next section, we detail general challenges due to the special characteristics of the current young generation, Generation Z.

\section{Special Characteristics of Generation Z}

It is difficult to decide whether a special feature of a generation is really unique or only comes from the age of the generation (Parry \& Urwin, 2011). Levickaite (2010) believes that technological, social, and political changes are the factors that affect the characteristics of generations. Regarding these changes, we should not pay attention to the age, but the way in which the change is experienced, as these processes leave a mark on people's behavior and thinking. In this paragraph we summarize the main 
characteristics of Generation $\mathrm{Z}$ in order to get more information about the possible attitude of the Generation $Z$ toward responsible innovation.

Interpreting the characteristics of future researchers (Generation $Z$ ) in terms of science education and its implementation, this generation reportedly does not prefer written texts, and their processing methods appear to be more nonlinear. According to the literature, they are able to simultaneously deal with several tasks at the same time, can access information they are interested in very quickly via a variety of channels (Oblinger \& Oblinger, 2005), and are more technological saturated and formally educated than other generations (McCrindle \& Wolfinger, 2009).

The idea that Generation $\mathrm{Z}$ feels the rapidly changing digital world their own natural environment (Connaway, Radford, Dickey, Williams, \& Confer, 2008; Oblinger \& Oblinger, 2005; McCrindle \& Wolfinger, 2009) has also important impact on the way to educate science. This generation speaks the language of technology as their own "mother tongue," and they consider everyone else as a digital immigrant having an "accent" (Prensky, 2001). This can cause tension between the different generations, particularly in education, as teachers who teach the younger generations sometimes feel they do not speak their "language." In addition, Generation $\mathrm{Z}$ is very education-oriented, but they learn differently as their predecessors (Barnes, Marateo, \& Ferris, 2007). They require self-directed and interactive learning opportunities, and they even need constant feedback (Glenn, 2000). They use digital devices not just for fun but for learning too (Barnes et al., 2007). These expectations also affect education: Generation $\mathrm{Z}$ requires radically different methods and curricula. This is a worldwide megatrend, and its recognition is necessary, but not a sufficient condition for a new generation education system. Otherwise, it can lead to communication disruption between the teacher and the students, and effective transfer of knowledge will not happen (Means, 2010).

The novelty in the life of the youngest generation is a natural consequence of innovation. They like generating changes, i.e., they are not passive observers of these changes only. Thus, we can hypothesize that they are perceptive to novelties, in fact, far more receptive than the former generations. Hence, they could be more open-minded toward the concept of responsible innovation. The members of Generation $\mathrm{Z}$ display greater openness to changes than the previous generations. During the implementation of responsible innovation, their responsiveness to change can be very important.

Using devices, which are suitable for multitasking, is important for the Generation $\mathrm{Z}$; thus, these people expect the continuous renewal mostly from these devices (Oblinger \& Oblinger, 2005). Young people are accustomed to fast and continuous flow of information and constant online presence. They communicate more easily in virtual space than in person. As a result, most of their contacts are not personal but online. Thus, digitalization plays a crucial part in their lives (Oblinger \& Oblinger, 2005). A flexible and tolerant attitude characterizes the younger generation.

The awareness of responsibility and the green, eco-friendly thinking appears increasingly in the mentality of Generation Z (Grail Research, 2011; McCrindle \& Wolfinger, 2009). They pay greater attention to the environment than the former generations. According to the Nielsen Global Report (2015), Generation Z would be willing to pay more for the products manufactured by companies which are environmentally conscious and committed to social problems. All these features of the Generation $Z$ provide a more stable basis on the acceptance and practical implementation of responsible innovation than previous generations. 
The above-mentioned characteristics of generations and their classification can be interpreted in a global context, as most generational features are valid regardless of geographic boundaries. However, this is complemented by the assumption that there may be differences in characteristics between developed and developing countries (McCrindle \& Wolfinger, 2009). In this study, we also share this point of view; thus, we interpret the main features of the different generations at global level, since, in the case of younger generations, we may talk about a more coherent group due to the impacts of globalization on their lives even if they live in different parts of the Earth. Besides the different characteristics of generations among countries, the main features of generations within a country are not necessarily uniform.

\section{Socio-technical Integration Among Potential Scientists}

The main characteristics of the Generation $\mathrm{Z}$ discussed in the previous section have pointed out that in case of applying science education in practice, we should not think of classic classroom teaching and traditional classroom solutions only but more modern techniques, too. In order to address this challenge, we analyzed the methods that were used to incorporate RRI thoughts into practice (see, e.g., Arentshorst, de Cock Buning, \& Broerse, 2016; Deák \& Lukovics, 2014; Fisher, 2007; Flipse \& Osseweijer, 2013; Imreh-Tóth \& Imreh, 2014; Kimmel, Toohey, \& Delborne, 2016; Okada, 2016; Panzda \& Ellwood, 2013; Pavie \& Carthy, 2014; Ravesteijn, Liu, \& Yan, 2015; Schuurbiers, 2011). We found that the methodological logic of Socio-Technical Integration Research (STIR) method seems to be a good solution, though it has been tested only among active researchers.

\section{The STIR Method}

The Socio-Technical Integration Research (STIR) supports interactions among experts of different disciplines (primarily social and natural sciences), who then collaboratively reflect on the context in which the innovative work is carried out, thereby aiming to broaden research decisions beyond the mere technical work (Fisher \& Schuurbiers, 2009). During the implementation phase of STIR, the STIR investigator is embedded in the daily operation of the natural science research group. The investigator visits the laboratory 2-3 times per week usually for 12 weeks and interacts with research participants following a semi-structured protocol. The protocol is derived from a decision model and is structured around questions regarding what the participant is doing and why, how else he/she can do it, and what impacts he/she expects (Fisher, 2007). Owing to the intensity of the interactive method, STIR studies tend to involve a small number of participants, usually between two and ten in total including both high- and low-interaction participants as well as controls (Fisher \& Mahajan, 2006; Flipse \& Osseweijer, 2013). Results are assessed using the midstream modulation framework (Fisher \& Mahajan, 2006) and take the form of changes over time in learning, deliberation, and behavior. Pre-study and post-study interviews are administered to measure changes in reflexive awareness as indicated by both direct reporting and using discourse analysis (Fisher \& Mahajan, 2006; Flipse \& van de Loo, 2018). 
STIR studies have documented changes in reflexive learning, value deliberation, and material practices in laboratories located across over a dozen nations on three continents. Thus, STIR investigators have generally found that the socio-ethical sensitivity of participating scientists and engineers increased, and the participants themselves found this learning to have practical value (Fisher \& Rip, 2013; Fisher \& Mahajan, 2006; Flipse \& van de Loo, 2018; Flipse \& Osseweijer, 2013; Flipse, van der Sanden, \& Osseweijer, 2014; Lukovics \& Fisher, 2017; Schuurbiers, 2011). In the followings, we detail how the STIR method was adapted to university undergraduate circumstances to test whether it is a good tool in science education or not.

\section{Adjusting STIR to Science Education: Methodological Background}

Considering the particular target group of researchers-in-the-making, as well as the suggestions and observations made during the two previous Hungarian STIR studies (Lukovics \& Fisher, 2017), we adjusted the original STIR method to higher education environment with the following modifications:

- Focus group discussion instead of laboratory (working) environment: since the members of our target group were current university students, it was not possible to apply STIR to actual research decisions because of the absence of active research work and laboratories. As a result, in this study, the 12-week-long interaction was carried out in a form of focus group discussions. The focus group format has not previously been used for STIR, although it has been used in a workshop setting (e.g., Fisher, 2010); in both cases, it enables the participation of a larger number of researchers, which is an important step in science education insofar as the general aim is to increase the RRI-awareness of as many young researchers as possible.

- Focusing on selected historical examples instead of daily research decisions: although the participating students have already carried out independent research work, they did not have their own research topic wherewith they could work on a daily basis. As a substitute we focused on issues which were strongly related to the aspects of RRI (e.g., environmental or socio-ethical factors) including nuclear chain reaction, aerosol sprays, Freon's, smart phones, Pokemon Go, the use of animals for research purposes in pharmaceutical and cosmetic industry, and the Takata airbag.

- Introducing "Step Zero": we followed the recommendations of Lukovics and Fisher (2017) to overcome the time challenges of discussing basic social, ethical, and economic issues of science and technology in the context of a developing economy; more specifically, the participating students were asked to deliver short presentations on the issues that emphasized the RRI aspects of these issues.

- Considering economic aspects: in light of the Eastern-European setting and following both Flipse at el. (Flipse \& Osseweijer, 2013) and Lukovics and Fisher (2017), we added economic aspects to the societal and technical aspects both to further inform but also to engage the participants.

- Scaling answers: The original STIR method does not provide any tools to statistically measure and analyze the changes of thinking. Flipse et al. (2013) introduced a tool for this purpose. Similarly, in our research, we asked participants to fill out a questionnaire using a scale of $1-6$, before and after the STIR study, as well as at the 
halftime mark (7th week). This approach allows one to more systematically measure weekly changes in the thinking of students compared to the reference state as well as to quantitatively illustrate the magnitude of change. In statistical sense, this type of instrument moves STIR to a higher measurement level, which expands opportunities for analysis.

- Investigators with a specialized focus: in order to systematically coordinate the social and ethical aspects being inquired into, three STIR investigators who each focused on a different RRI dimension took part in the STIR research. This step was intended to decrease (although not entirely eliminate) a limitation of the STIR approach, namely, that no single STIR investigator can be completely familiar with all conceivable subjects and relationships pertaining to the entirety of the social sciences and humanities.

\section{STIR Focus Group Versus Formal Education}

In the weekly focus group, we involved seven science students (volunteers) in the discussion for 12 weeks (Table 1). Most of these participants envisioned themselves as future researchers. As they were in an MSc training program, they only experienced the university laboratory environment during their studies and when preparing their BSc thesis work; thus, only three had any research experience, and this was extremely limited. One studied the operation of hearing aids using electrodes; the second investigated the effects of noise on normal hearing using electrodes; and the third worked on the programming of hearing aids as well as carried out biological experiments.

During the weekly focus group, we attempted to enhance the natural science-related way of thinking of the students with social science aspects (environmental, ethical, social, and economic issues) and to raise their awareness of the possibility that research decisions can have ramifications in the future. Each week, one student had to prepare a short presentation as basis for a discussion. Then with the guidance of the investigator, the participating students as a group used the STIR protocol to identify the original

Table 1 Participants of the research

\begin{tabular}{lll}
\hline $\begin{array}{l}\text { Characteristic } \\
\text { features }\end{array}$ & Focus group & In-class group \\
\hline $\begin{array}{l}\text { Method } \\
\begin{array}{l}\text { Students' major field of } \\
\text { study }\end{array}\end{array}$ & $\begin{array}{c}\text { Molecular Bionics } \\
\text { (Faculty of Science and Informatics) }\end{array}$ & $\begin{array}{c}\text { Traditional (formal) education } \\
\text { Chemistry (Faculty of Science } \\
\text { and Informatics) }\end{array}$ \\
$\begin{array}{l}\text { Nature of communication } \\
\text { Number of students }\end{array}$ & $\begin{array}{c}\text { Bidirectional } \\
\text { Time of research }\end{array}$ & $\begin{array}{l}\text { Unidirectional } \\
\text { September 6, 2016-December 6, 2016 }\end{array}$ \\
Role of the students & $\begin{array}{c}\text { Active or high interaction persons } \\
\text { (participant) }\end{array}$ & $\begin{array}{c}\text { September 6, 2016-December 6, } \\
\text { 2016 }\end{array}$ \\
Aim & Joint thinking & $\begin{array}{c}\text { Passive, control, or no interaction } \\
\text { persons (typical student role) }\end{array}$ \\
\end{tabular}

Source: Own construction 
objective, main decision points, alternatives, and unexpected side effects of the innovation. The process is illustrated in Fig. 1.

In addition to the focus group, and for comparative purposes, we involved an in-class group (49 volunteers) of university students that represented traditional (formal) education. The in-class group regularly visited lectures on economic, social, and ethical aspects of scientific research and results. Unlike the focus group, the in-class group did not follow any form of the STIR protocol. The main differences between the two groups (focus group and in-class) were thus (1) the direction of communication and (2) the participation of students: in the case of the focus group, there was an intense bidirectional communication and joint thinking, while in the in-class group, there was only unidirectional communication, i.e., students passively listened to a talk.

In the following, we discuss the main results of the focus group and in-class sessions with an emphasis how consciously the RRI aspects were integrated in the way of thinking of the university students.

\section{Results of the STIR Interactions}

Comparing the results of the pre-study and post-study questionnaires, our most important finding is that the answers given before the interactions were intuitive, and the students could not give reasons for them. After the interactions, the learning process appeared in the significant increase of consciousness: the final answers were more

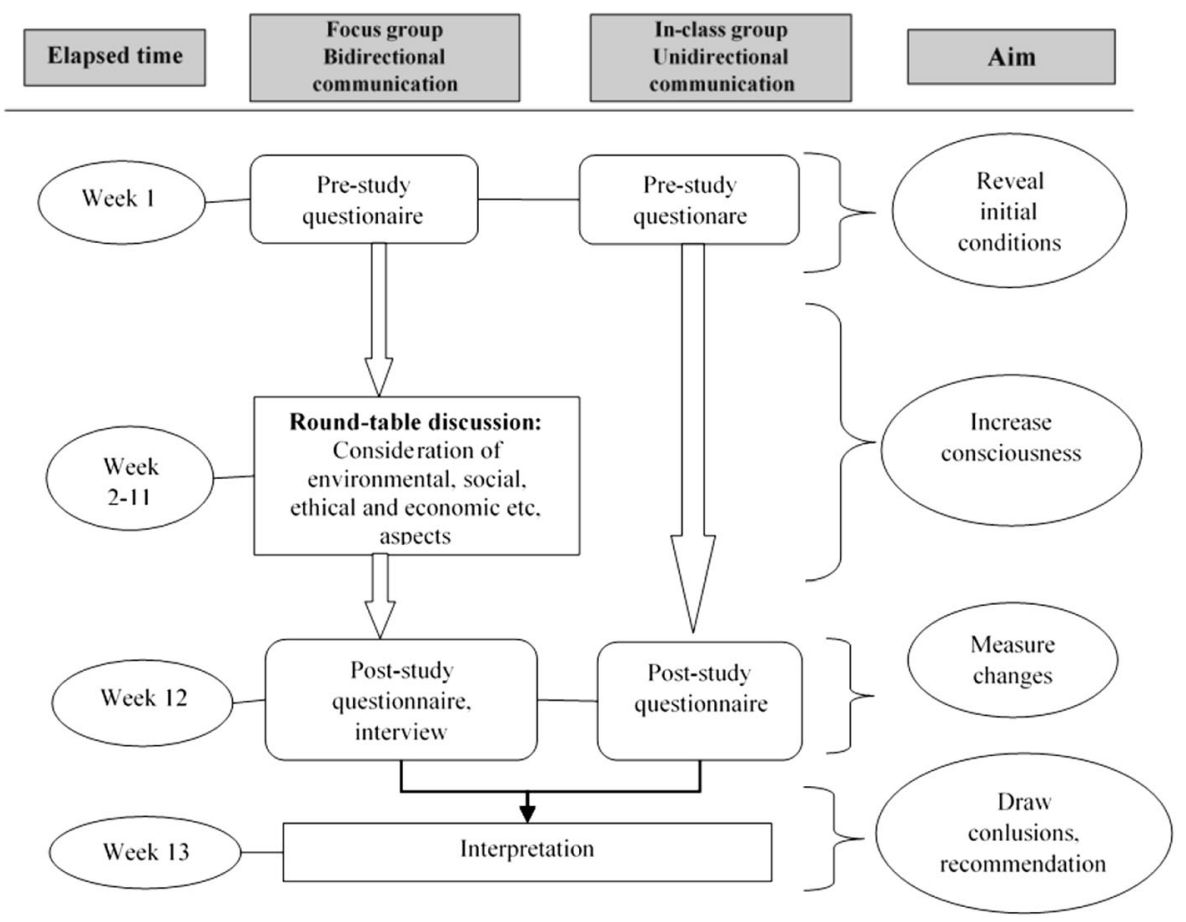

Fig. 1 Methodology of the research. Source: Own construction 
replete with technically detailed (and correct) explanations. The main questions were as follows:

1. As a student of the Faculty of Science, how much do you think it is important to have access to social science knowledge during your studies?

2. How important do you consider the environmental aspects to be taken into account in the process of research and development in natural sciences?

3. How important do you consider the social aspects to be taken into account in the process of research and development in natural sciences?

4. How important do you consider the economic aspects to be taken into account in the process of research and development in natural sciences?

5. How important do you consider the ethical aspects to be taken into account in the process of research and development in natural sciences?

6. To what extent do you think it makes sense to integrate social, economic, and ethical issues into the process of research and development and innovation in natural science?

Initially, the students were skeptical about the importance of social science knowledge. It was clear that their interests were limited to the natural sciences and that they drew a borderline between these two fields of science. During the interactions, however, their intellectual horizon widened week by week, and their interest in social science knowledge increased. "Opportunities [for increasing the social relevance of natural science] have expanded with social science knowledge, compared to what we have known until now" claimed one student during the post-study interview. For another student: "During those 12 weeks, it turned out that it is important to see many aspects of things; because we might not notice any errors that are [nevertheless] present, because we do not know that they exist." These responses suggest the Generation Z characteristics of openness and flexibility.

Regarding social and environmental aspects, we also observed the Generation $\mathrm{Z}$ characteristic of eco-friendly thinking. For instance, one student stated that "The environmental aspect is the most important aspect. If we would care about [environmental aspects] that would modify the research [in a positive manner]." By contrast, we detected greater environmental awareness during the pre-study interview than did Lukovics and Fisher (2017) in their STIR study involving active researchers. Importantly, although they attributed great importance to these aspects in the first week, during the post-study interviews, most of the students expressed greater reflexive awareness about their own ecological values. As one student put it, "At the beginning I could not confirm my answer, just as [I could] now." In other words, their initial answers were based on intuition. Students also became more aware of opportunities for more socially and environmentally responsible approaches. Thus, according to a student, "There were certain things, what we have discussed and I have never thought of; for example, how much garbage we produce during research. I never realized that somehow it could be decreased."

Learning about economic aspects was the most noticeable result of the STIR interactions. At the beginning of the discussions, we experienced resistance and even outright refusal, as some students did not want to even consider this topic. "As a natural scientist, I do not want to deal with the economic aspects of my research." Subsequently, we discovered that complexity and responsibility were two reasons why 
students resisted this topic: "Who deals with economic issues, is in charge of budget, [and] has subordinates, but I do not want to deal with these things." Nevertheless, when we discussed the commercialization of one student's knowledge, the participants identified trust among stakeholders as an important issue. During the post-study interviews, all seven students considered it important to put an emphasis on economic aspects. As one stated, "It is an important aspect, for instance, to divide the budget sufficiently, and not to run out of it prematurely", and another stated that "when you found a business or a company, it is useful".

Students initially thought that ethical aspects had very little bearing on research decisions, a finding that was similar to what Lukovics et al. (2016) found in case of active Hungarian researchers. "Test animals are purpose-bred animals, and the success of the experiment is the primary objective, everything is subordinated to this, thus the animal is. Of course, ethical permit must be complied with, but nothing more. " There were departures from this attitude, however. One student stated that stricter regulations on animal testing should be introduced. Another student reckoned that "Imagine if experiments were carried out to prevent global warming, but these experiments would cause a major loss. They would save the Earth, so I think, these experiments would be within ethical limits." Accordingly, this person thinks that the end justifies the means; however, there are certain limits.

As time went by, the students placed greater importance on the above-mentioned aspects, however, and thought that social, environmental, and ethical aspects would be worth integrated into RDI processes (Table 2). Almost all students agreed with the statement that "If any of these topics arises when a researcher writes a research plan..., it is important to include and summarize them at the end." As one stated, "we should always deal with these questions, during at each point of the process." Students thus eventually agreed that starting from the preparation of research projects throughout the research phase, it is important to keep RRI aspects in mind. During the 12-week-long study, the horizon of the participants thus seems to have expanded and their sensitivity raised toward sociological knowledge. One student concluded during the post-study

Table 2 Changes in the focus group

\begin{tabular}{|c|c|c|c|c|}
\hline & $\begin{array}{l}\text { Environmental } \\
\text { aspects }\end{array}$ & $\begin{array}{l}\text { Social } \\
\text { aspects }\end{array}$ & Economic aspects & Ethical aspects \\
\hline Change in scaling & No change & No change & $\begin{array}{l}\text { Changed in a positive } \\
\text { direction }\end{array}$ & $\begin{array}{l}\text { Changed in a } \\
\text { positive } \\
\text { direction }\end{array}$ \\
\hline $\begin{array}{l}\text { Participants' attitude } \\
\text { toward the aspects }\end{array}$ & Open & $\begin{array}{l}\text { Open, } \\
\text { actively } \\
\text { engaged }\end{array}$ & $\begin{array}{l}\text { Initially closed and } \\
\text { resistant to taking } \\
\text { responsibility; } \\
\text { eventually more } \\
\text { open }\end{array}$ & $\begin{array}{l}\text { A more divisive } \\
\text { topic; } \\
\text { thus students } \\
\text { were } \\
\text { indeterminate }\end{array}$ \\
\hline $\begin{array}{l}\text { Ratio of answers to } \\
\text { open questions that are } \\
\text { deemed factually correct }\end{array}$ & \multicolumn{3}{|c|}{$\begin{array}{l}\text { Significant growth } \\
\text { Initially, there were no factually } \\
\text { correct answers; eventually } \\
\text { this value increased }\end{array}$} & $\begin{array}{l}\text { Significant growth; } \\
\text { the number of } \\
\text { factually correct } \\
\text { answers doubled }\end{array}$ \\
\hline Level of awareness & \multicolumn{4}{|c|}{ Positive change, increased levels of factual and reflexive awareness } \\
\hline
\end{tabular}

Source: Own construction 
interview, "Before this [focus group], I did not think that what I do has impacts on many things." The awareness of students also seems to have increased toward social science and its application to research: "until now I haven't thought of important things related to my research, and I am sure, I am going to think in a different way from now." The responses given by participants indicate a greater value placed on societal issues, which did not played a significant role in their thinking at the beginning of this research. "I have just realized that there are many things that I do not know about! Recently, I have asked a lot of questions from the [laboratory director], how does he do it or does he deal with these aspects."

We also investigated whether or not this generation has an outlook that is conditioned by the post-socialist environment, which was revealed to be among the currently active researchers in the Hungarian STIR pilots (Lukovics et al., 2016). Based on the students' opinions and experiences, the attitude patterns evolved by a post-socialist outlook in the case of Generation $\mathrm{Z}$ are less characteristic than in the Hungarian pilots among senior researchers. This could be an important input when adapting STIR methodology to other countries where the post-socialist mentality is still present at any levels.

In summary, we found that during the 12 weeks of interactions, the students' intellectual horizon widened; their sensitivity toward sociological knowledge increased; the complexity of their thinking increased; and their perception of the value of social science increased.

\section{Results in the In-Class Group}

There was also a change in the in-class group - which members only participated in unidirectional communication. This change, however, is minor and much smaller than in case of the focus group. Similar to the students in the focus group, students placed higher importance on environmental, social, ethical, and economic aspects after the 12th week than they did initially. Unlike the students in the focus group, however, they could not justify the higher importance. Thus, the awareness behind their questionnaire answers remained lower than in the focus group, and we only can assume intuitive answers. Concerning environmental aspects, participants highlighted that "it is important to look for alternative solutions to environmental problems...." In terms of the importance of social considerations, the value of the scaling (90\%) significantly increased, which was explained by the fact that "the research should be carried out for the benefit of society and the discoveries made in natural sciences should be beneficial for the society." Students noted that although the main emphasis is on the results, consideration should also be given to make the research process more economical. Only two-thirds of the students $(63.2 \%)$ thought initially that ethics had a central role in the research process and its outcome, while at the end of the 12 weeks, this ratio was above $75 \%$. "The most important role of ethics is to remain within certain limits and to avoid any discrimination," while others believed that "the end sanctifies the means, and scientific progress often requires nonethical sacrifices."

These results suggest that there is a change in the students' thinking during the lectures via the knowledge transfer relating RRI, but, in the focus group, we observed a markedly greater shift in the participants' horizon broadening than here. 


\section{Summary of Results}

Both the focus group participants and those students who attended the in-class lectures displayed an increased sense of the importance of RRI in relation to research and innovation; however, the focus group participants displayed more dramatic changes in this direction as well as a deepened ability to reason about them. Since both groups underwent a change, but only in the focus group did the consciousness behind their answers significantly improve, we assume that the constant feedback and interactive mode of education contributed to this change. The difference suggests that traditional education is not as effective as a more interactive setting, which we would expect in the case of Generation Z. It appears that in the case of the in-class group, it was more difficult to capture the attention of students, and thus their responsiveness is also limited.

\section{Recommendations}

As we found a gap in the literature how the RRI principles can be taught to researchers-in-the-making which is suitable for the special needs of the Generation $Z$, we tested the STIR method in these circumstances. Based on the theoretical knowledge on the characteristics of the Generation Z, the original STIR method was a bit modified. If the aim is to integrate RRI in practice, it is really important that the RRI thoughts are integrated in science education. Integrating RRI in higher education, the RRI principles will be sustained in long term. The findings of our research also suggest that to ensure that the notion of responsible research and innovation becomes useful and applicable knowledge, traditional in-class education should be supplemented with more interactive learning activities. It is in line with the needs of the Generation Z: constant feedback, digital tools, and active engagement are necessary for them in education (Barnes et al., 2007; Glenn, 2000). The findings suggest that active participation and common consideration of topics are valuable and that approaches developed in a research setting, such as STIR, may be a useful tool for this kind of science education. We also found that the efficiency of STIR during this research was relatively high among young potential, but still not active - researchers in Hungary, a result that is similar to the pilot projects carried out among active researchers in the same country (Lukovics et al., 2016).

These conclusions also suggest the following two-step model for science education that might accelerate the practical implementation of RRI into the way of thinking of the young - to-be - researchers:

1. Foundation: Knowledge-transfer via unidirectional communication, which was applied in the in-class group. Our results suggest that RRI can be integrated into the higher education system using traditional means and that this would provide a promising basis for future researchers to commence their work in accordance with RRI concepts and practices. However, in-class learning appears to merely provide a foundation for deeper skills and learning that would provide for more effective science education. That is, it is important for the Generation $\mathrm{Z}$ to acquire RRI- 
related knowledge through traditional science education, but it should be extended with tools adjusting to the special needs of Generation Z (Parry \& Urwin, 2011).

2. Deepening: The foundation could be extended by pedagogical methods that require active participation, critical thinking, and concentrated reflection from a young student resulting in reflexive learning. That is, emphasizing creativity and innovative, useful, and engaging experimentations with knowledge (Hayden et al., 2011) may be more promising in science education. And Socio-Technical Integration Research, which is applied in our research, is based on dialogues, joint thinking, and discovery - all these focus on the required active engagement. It appears to have enabled the students to assimilate some of the key the concepts and values of RRI and to help ensure that RRI becomes an inner motivation and not simply an external constrain.

The foundation and deepening together would be intended to lead to lasting and sustainable RRI-related ways of thinking. In addition, we highlight based on the experiences of the previous Hungarian STIR pilot projects that, in accordance with international best practices, if we want to improve young, Hungarian, possible researchers' preparedness to RRI, it would be beneficial to start with the basics, along with the following recommendations:

1. Integration of "Step Zero" into the method: it is important to maximize the time of STIR application and minimize time in which we define the missing basic concepts of RRI (Lukovics et al., 2016). In the present study, there was a similar Step Zero, namely, the weekly student presentation. Regardless of the form it takes, some type of Step Zero should be integrated, where the basic concepts are being acquired outside the STIR time horizon (it is not necessarily held before the start of STIR). This can be a starter seminar, an individual preparation before the interactions on the field of a guided topic, or some other preparatory activities using the digital tools - as they are essential for the Generation $Z$ members (Barnes et al., 2007).

2. Integration of social science and humanities foundational courses into the natural science education: comparative research suggests that STIR is more effective in countries where social science courses are present in a greater number within natural science education (Lukovics et al., 2017). The present study suggests that a slight enlargement of the intellectual horizon can be achieved via introducing it into the education. If the previous suggestion was defined as the Step Zero, then this step might be the "step minus one."

3. It is recommended to strengthen the role of feedback: in line with Glenn (2000), the students of Generation Z need constant feedback. The discussions in the STIR support this need. During our research, there was a noticeable change in students' way of thinking, their horizon broadened; however, they admitted that they did not know how to integrate these aspects in their own practical work. To solve this problem, we recommend that later, after 1 or half year, during the practical/ laboratory work, we should investigate how or in what extent the horizon broadening occurred after the 12-week-long study.

These steps are not exclusive or selective, since we assume that strengthening only the education would not result in more ethical or more environmentally responsible attitude 
in a profit-oriented capitalist environment. We suppose that all aforementioned steps should be implemented if the aim is to integrate RRI into practice in the case of future researcher generation.

The above recommendations are about the modifications of the STIR method to adjust to the needs of science education and of the needs of the Generation Z. However, higher education institutions and their staff need to be prepared for this. The leaders and professors of these institutions need to be committed to the RRI principles, they also need to be educated; otherwise modifying the STIR method does not cause any result.

\section{Conclusions}

The aim of the current exploratory study was to test how the RRI-awareness of researchers-in-the-making studying can be raised. Taking into account the special characteristics of the Generation $\mathrm{Z}$ (e.g., nonlinear learning, multitasking, digital environment), we assumed that there should be a method which is more applicable in this generation. Socio-Technical Integration Research has such a methodological logic which could be adjusted to some of these special features. In order to test our assumption, we involved young, Hungarian to-be researchers (i.e., students from the University of Szeged) in our analysis, and we tested the STIR among them.

According to this method and the results gained, we tentatively conclude that the STIR method is able to broaden young potential scientists' horizon and to effectively realize science education on RRI among the Generation $\mathrm{Z}$ to-be researchers. Furthermore, it seems more effective than the traditional classroom education, where the knowledge transfer happens without intensive joint thinking. According to our findings, there is a promising basis for integrating and using responsible innovation in practice in the case of active researchers if we pay attention to students. It is also important to study results over time in order to analyze how previous students use the learned information during their active researches. It is also an important lesson that the STIR method should be adjusted to the characteristics of the target group but can be successfully used as an effective tool in science education to raise the awareness of university students toward RRI.

There are several limitations of this research that should be noted. We argued that STIR could be effectively used in science education because it can contribute to increase the awareness of natural science students toward social issues. Of course, it should go without saying that no research, management, or pedagogical method - with or without traditional educational support - is sufficient to ensure RRI; these are at best supportive and "soft" interventions (Fisher \& Rip, 2013). Another limitation has to do with topics discussed. Despite assigning separate STIR investigators with expertise in predetermined content areas, the risk still exists that during the STIR interactions, the areas and topics that are most dominant are those which belong to the special interest and knowledge of the STIR-researcher. Finally, it is clear that our sample was not representative and that the training program in which the students participate (e.g., physics versus biology) might also influence the results. In future research, the sample can be extended to include and compare other training programs, universities, and national settings.

In spite of the limitations, our exploratory study showed that there could be a nontraditional education method adjusting to some of the special features of the 
Generation $\mathrm{Z}$ which is able to increase the RRI awareness of researchers-in-the-making before they start their active research career. The new application area of the STIR method resulted in hopeful findings, since it was able to raise the attention of the youngest generation to social issues, while the common thinking provided them such knowledge and skills which the students - in contrast to traditional education methods - not only learned but considered multiple times and became more able to reason critically and effectively about.

Funding Information Open access funding provided by University of Szeged (SZTE).

Open Access This article is distributed under the terms of the Creative Commons Attribution 4.0 International License (http://creativecommons.org/licenses/by/4.0/), which permits unrestricted use, distribution, and reproduction in any medium, provided you give appropriate credit to the original author(s) and the source, provide a link to the Creative Commons license, and indicate if changes were made.

\section{References}

Adam, B., \& Groves, G. (2011). Futures tended: care and future-oriented responsibility. Bulletin of Science Technology Society, 31(1), 17-27.

Ahrwiler, P., Gilbert, N., Schrempf, B., Grimpe, B., \& Jirotka, M. (2019). The role of civil society organisations in European responsible research and innovation. Journal of Responsible Innovation, $6(1), 25-49$.

Arentshorst, M. E., de Cock Buning, T., \& Broerse, J. E. W. (2016). Exploring responsible innovation: Dutch public perceptions of the future of medical neuroimaging technology. Technology in Society, 45(May 2016), 8-18.

Arnaldi, S., Quaglio, G., Ladikas, M., O'Kane, H., Karapiperis, T., Srinivas, K. R., \& Zhao, Y. (2015). Responsible governance in science and technology policy: reflections from Europe, China and India. Technology in Society, 42(August 2015), 81-92.

Ballas, D. \& Lupton, R. \& Kavroudakis, D. \& Hennig, B. \& Yiagopoulou, V. \& Dale, R., \& Dorling, D. (2012): Mind the gap: education inequality across EU regions. NESSE Network of Experts for the European Commission: Brussels, Belgium.

Barnes \& Noble College (2017): Getting to know Gen Z - exploring middle and high schoolers' expectations for higher education. https://next.bncollege.com/wp-content/uploads/2017/06/15-BNCB-GenZ-ResearchReport_v4.pdf Accessed: 28 May 2018.

Barnes, K., Marateo, R. C., \& Ferris, S. P. (2007). Teaching and learning with the net generation. Innovate. Journal of Online Education, 3(4), 1.

Beck, U. (1992): Risk society: towards a new modernity. Sage Publications.

Buzás, N., \& Lukovics, M. (2015). A felelősségteljes innovációról. [On responsible innovation]. Közgazdasági Szemle, 62(4), 438-456.

Chorus, C. \& van Wee, B. \& Zwart, S. (2012): TPM Catalogue. Concepts, theories, methods. Delft University of Technology, Delft.

Connaway, L. S., Radford, M. L., Dickey, T. J., Williams, J. D. A., \& Confer, P. (2008). Sensemaking and synchronicity: information-seeking behaviors of millennials and baby boomers. Libri, 58(2), 123-135.

Deák, I., \& Lukovics, M. (2014). Responsible innovation and R\&D\&I controlling. In N. Buzás \& M. Lukovics (Eds.), Responsible Innovation (pp. 101-120). Szeged: University of Szeged.

Dosi, G., Grazzi, M., \& Moschella, M. (2015). Technology and costs in international competitiveness: From countries and sectors to firms. Research Policy, 44(10), 1795-1814.

EC (2013): Responsible Research and Innovation (RRI ), Science and Technology. Special Eurobarometer 401. European Commission, Brussels. ec.europa.eu/public_opinion/ archives/ebs/ebs_401_en.pdf Accessed: 14 June 2016.

EC (2014): Responsible Research and Innovation. Europe's ability to respond to societal challenges. European Commission, Brussels. https://ec.europa.eu/research/swafs/pdf/pub_rri/KI0214595ENC.pdf Accessed: 11 June 2016. 
EC (2015): Science education for responsible citizenship. Directorate-General for Research and Innovation. European Comission. Brussels.

EC (2017): Horizon 2020. Work programme 2018-2020. 16. Science with and for Society. European Commission, Brussels. http://ec.europa.eu/research/participants/data/ref/h2020/wp/2018-2020 /main/h2020-wp1820-swfs en.pdf Accessed: 28 May 2018.

Edquist, C. (2005): Systems of innovation approaches. Their emergence and characteristics. In Edquist, C. (ed): Systems of innovation. Technologies, institutions and organizations. London - New York: Routledge. 1-35.

Fensham, P. (2008). Science education policy-making. Paris: UNESCO.

Fisher, E. (2007): Integrating Science and Society in the Laboratory. Presentation. Center for Integrated Nanotechnologies. Los Alamos National Laboratory. Los Alamos, NM.

Fisher, E. (2010): Public value integration in science policy. Science of Science Policy Measurement Workshop. Office of Science and Technology Policy. National Press Club, Washington D.C. December 2-3.

Fisher, E. \& Mahajan, R. L. (2006): Midstream modulation of nanotechnology research in an academic laboratory. Paper presented at the American Society of Mechanical Engineers International Mechanical Engineering Congress and Exposition, Chicago.

Fisher, E. \& Rip, A. (2013): Responsible innovation: ,multi-level dynamics and soft intervention practices. In: Owen, R. \& Bessant, J. \& Heintz, M. (eds.): Responsible innovation: Managing the responsible emergence of science and innovation in society, John Wiley \& Sons, 165-183.

Fisher, E., \& Schuurbiers, D. (2009). Lab-scale intervention. Science \& Society Series on Convergence Research. EMBO Reports, 10(5), 424-427.

Flipse, S. M. \& van der Sanden, M. C. A \& Osseweijer, P. (2013): Midstream modulation in biotechnology industry: redefining what is 'part of the job' of researchers in industry. Science and Engineering Ethics, 19(3), 1141-1164.

Flipse, S. M., \& van de Loo, C. J. (2018). Responsible innovation during front-end development: increasing intervention capacities for enhancing project management reflections on complexity. Journal of Responsible Innovation, 5(2), 1-16.

Flipse, S. M., van der Sanden, M. C., \& Osseweijer, P. (2014). Improving industrial R\&D practices with social and ethical aspects: aligning key performance indicators with social and ethical aspects in food technology R\&D. Technological Forecasting and Social Change, 85(June 2014), 185-197.

Forsberg, E-M. \& Quaglio, G. \& O'Kane, H. \& Karapiperis, T. \& Woensel, L. von \& Arnaldi, S. (2015): Assessment of science and technologies: advising for and with responsibility. Technology in Society, 42, (August 2015), 21-27.

Fourez, G. (1997). Scientific and technological literacy as a social practice. Social Studies of Science, 27, 903936.

Geck, C. (2007). The Generation Z connection: teaching information literacy to the newest net generation. In E. Rosenfeld \& D. V. Loertscher (Eds.), Toward a 21st-Century School Library Media Program. Plymouth: The Scarecrow Press and Hi Willow Research and Publishing.

Gibbons, M., Limoges, C., Nowotny, H., Schwartzman, S., Scott, P., \& Trow, M. (1994). The new production of knowledge: the dynamics of science and research in contemporary societies. Sage Publications.

Glenn, J. M. (2000). Teaching the net generation. Business Education Forum., 54(3), 6-14.

Grail Research (2011): Consumers of tomorrow: insights and observations about Generation Z. http://www. integreon.com/pdf/Blog/Consumers_of_Tomorrow_Insights_and_Observations_About_Generation_ Z_246.pdf Accessed: 23 July 2016.

Gurría, A. (2011): Skills for the 21st century: from lifetime employment to lifetime employability. OECD

Hayden, K., Ouyang, Y., Scinski, L., Olszewski, B., \& Bielefeldt, T. (2011). Increasing student interest and attitudes in STEM: professional development and activities to engage and inspire learners. Contemporary Issues in Technology and Teacher Education, 11(1), 47-69.

Hin, G., Daigney, M., Haudebault, D., Raskin, K., Bouché, Y., Pavie, X., \& Carthy, D. (2015). Introduction to Responsible Innovation Criteria. Paris: Karim.

Holbrook, J. (2010). Education through science as a motivational innovation for education for all. Science Education International, 21(2), 80-91.

Hoop, E., Pols, A., \& Romijn, H. (2016). Limits to responsible innovation. Journal of Responsible Innovation, $3(2), 110-134$

Imreh-Tóth, M., \& Imreh, S. (2014). Entrepreneurship education for responsible innovation. In N. Buzás \& M. Lukovics (Eds.), Responsible innovation (pp. 73-84). Szeged: University of Szeged.

Inzelt, A., \& Csonka, L. (2014). Responsible science in societies. In N. Buzás \& M. Lukovics (Eds.), Responsible innovation (pp. 57-72). Szeged: JATEPress. 
Jenkins, E. (1999). School science, citizenship and the public understanding of science. International Journal of Science Education, 21, 703-710.

Khorseed, M. S. (2017). Learning from global pacesetters to build the country innovation ecosystem. Journal of the Knowledge Economy, 8(1), 177-196.

Kimmel, S. C., Toohey, N. M., \& Delborne, J. A. (2016). Roadblocks to responsible innovation: exploring technology assessment and adoption in U.S. public highway construction. Technology in Society, 44(February 2016), 66-77.s.

Levickaite, R. (2010). Generations X, Y, Z: how social networks form the concept of the world without borders. The Case of Lithuania. Limes, 3(2), 170-183.

Lukovics, M., \& Fisher, E. (2017). Socio-Technical Integration Research in an Eastern-European setting: distinct features, challenges and opportunities. Society \& Economy (forthcoming).

Lukovics, M., Fisher, E., \& Udvari, B. (2016). A felelősségteljes innováció iránti fogékonyság fejlesztése a gyakorlatban. [Improvement of sensitivity towards responsible innovation in practice.]. Marketing \& Menedzsment, 50(2), 3-18.

Lukovics, M., Flipse, S. M., Udvari, B., \& Fisher, E. (2017). A responsible innovation tool in a different innovation environment: the case of Socio-Technical Integration Research in Hungary and the Netherlands. Technology in Society, 51(11), 172-282.

McCrindle, M. \& Wolfinger, E. (2009). The ABC of XYZ: Understanding the global generations. The ABC of XYZ.

Means, B. (2010). Technology and education change: focus on student learning. Journal of Research on Technology in Education, 42(3), 285-307.

NASEM. (2018). The integration of the humanities and arts with sciences, engineering, and medicine in higher education: branches from the same tree. Washington, DC: The National Academies Press. https://doi.org/10.17226/24988.

Nielsen Global Report (2015): The sustainability imperative. New insights on consumer expectations. https://www.nielsen.com/content/dam/nielsenglobal/dk/docs/global-sustainability-report-oct-2015.pdf. Accessed: 13 April 2017.

Oblinger, D., \& Oblinger, J. (Eds.). (2005). Educating the Net Generation. Washington: EDUCAUSE.

Okada, A. (2016): Responsible research and innovation in science education report. Milton Keynes: The Open University - UK.

Olsen, R. V., \& Lie, S. (2011). Profiles of students' interest in science issues around the world: analysis of data from PISA 2006. International Journal of Science Education, 33(1), 97-120.

Owen, R. (2014). The UK Engineering and Physical Sciences Research Council's commitment to a framework for responsible innovation. Journal of Responsible Innovation, 1(1), 113-117.

Owen, R., Macnaghten, P., \& Stilgoe, J. (2012). Responsible research and innovation: from science in society to science for society, with society. Science and Public Policy, 39(6), 751-760.

Owen, R. \& Stilgoe, J. \& Macnaghten, P. \& Gorman, M. \& Fisher, E. \& Guston, D. (2013): A framework for responsible innovation. In Owen, R.; Bessant, J. \& Heintz, M. (Eds.). Responsible Innovation. Managing the responsible emergence of science and innovation in society. A John Wiley \& Sons, Ltd. United Kingdom, 27-50.

Panzda, K., \& Ellwood, P. (2013). Strategic and ethical foundations for responsible innovation. Research Policy, 42(5), 1112-1125.

Parry, E., \& Urwin, P. (2011). Generational differences in work values: a review of theory and evidence. International Journal of Management Reviews, 13(1), 79-96.

Pavie, X., \& Carthy, D. (2014). Addressing the wicked problem of responsible innovation through design thinking. In N. Buzás \& M. Lukovics (Eds.), Responsible Innovation (pp. 13-28). Szeged: University of Szeged.

Pavie, X., \& Egal, J. (2014). Innovation and responsibility: a managerial approach to the integration of responsibility in a disruptive innovation model. In J. van den Hoven et al. (Eds.), Responsible Innovation 1: Innovative Solutions for Global Issues (pp. 53-66). Dordrecht: Springer.

Prensky, M. (2001). Digital natives, digital immigrants part 1. On the horizon, 9(5), 1-6.

Ravesteijn, W., Liu, Y., \& Yan, P. (2015). Responsible innovation in port development: the Rotterdam Maasvlakte 2 and the Dalian Dayao Bay extension projects. Water Science and Technology, 72(5), 665-677.

Richter, J., Hale, A. E., \& Archambault, L. M. (2019). Responsible innovation and education: integrating values and technology in the classroom. Journal of Responsible Innovation, 6(1), 98-103.

Richter, J. A., Tidwell, A. S., Fisher, E., \& Miller, T. R. (2017). STIRring the grid: engaging energy systems design and planning in the context of urban sociotechnical imaginaries. Innovation: The European Journal of Social Science Research, 30(3), 365-384. 
Rip, A. (2016). The clothes of the emperor. An essay on RRI in and around Brussels. Journal of Responsible Innovation, 3(3), 290-304.

Schuurbiers, D. (2011). What Happens in the Lab: Applying midstream modulation to enhance critical reflection in the laboratory. Science and Engineering Ethics, 17(4), 769-788.

Shelley-Egan, C., Hanssen, A. B., Landeweerd, L., \& Hofman, B. (2018). Responsible Research and Innovation in the context of human cognitive enhancement: some essential features. Journal of Responsible Innovation, 5(1), 65-85.

Sinatra, G. M., Kienhues, D., \& Hofer, B. K. (2014). Addressing challenges to public understanding of science: epistemic cognition, motivated reasoning, and conceptual change. Educational Psychologist, 49(2), 123-138.

Spruit, S. (2014). Responsible innovation through ethics education: educating to change research practice. Journal of Responsible Innovation, 1(2), 246-247.

Stilgoe, J., Owen, R., \& Macnaghten, P. (2013). Developing a framework for responsible innovation. Research Policy, 42(9), 1568-1580.

Sutcliffe, H. (2013). A report on responsible research and innovation. London: Matter.

Swierstra, T. (2013). Nanotechnology and technomoral change. Ethica \& Politica/Ethics \& Politics, 15(1), 200-219.

Tihon, A., \& Ingham, M. (2011). The societal system and responsible innovations: freeing sustainable development from a deadlock. Journal of Innovation Economics, 2(8), 11-31.

von Schomberg, R. (2013). A vision for responsible research and innovation. In R. Owen, J. Bessant, \& M. Heintz (Eds.), Responsible Innovation (pp. 51-74). London: John Wiley.

Wynne, B. (2006). Public engagement as a means of restoring public trust in science? Hitting the notes, but missing the music. Community Genetics, 9(3), 211-220.

Publisher's Note Springer Nature remains neutral with regard to jurisdictional claims in published maps and institutional affiliations.

\section{Affiliations}

\section{Miklós Lukovics ${ }^{1} \cdot$ Beáta Udvari $^{1} \cdot$ Nikoletta Nádas $^{2} \cdot$ Erik Fisher $^{3}$}

Miklós Lukovics

miki@eco.u-szeged.hu

Nikoletta Nádas

nadas.nikoletta@gmail.com

Erik Fisher

efisher1@asu.edu

1 Faculty of Economics and Business Administration, University of Szeged, Kálvária sgt. 1, Szeged H6722, Hungary

2 First Hungarian Responsible Innovation Association, Pihenő Street 35., Szeged H-6728, Hungary

3 School for the Future of Innovation in Society, Arizona State University, Tempe, AZ 85287-5603, USA 